\title{
IMPLEMENTATION OF HEALTH PROMOTION STRATEGIES IN THE INTEGRATED SERVICE POST PARK PROGRAMS AT THE PUBLIC HEALTH CENTER PESANTREN I KEDIRY CITY
}

\author{
Kurniawan Edi Priyanto ${ }^{1}$, Byba Suhita ${ }^{2}$, Siti Farida ${ }^{3}$ \\ Postgraduate Program STIKes Surya Mitra Husada Kediri \\ kurniawan_edi_p@yahoo.com
}

\begin{abstract}
Health together with education and economy are the three pillars that greatly affect the quality of human resources. One form of community empowerment efforts in the field of health is to develop Integrated Service Post. Integrated Service Post Park is integrated service post development which is given additional services of Early Childhood Educational Programs and the development of family toodler coaching. To optimize the function of Integrated Service Post Park, it is neccesary to have a special fasicilitator and focus on monitoring, assisting cadres to evaluate and develop Integrated Service Post Park. The purpose of this study is to know the implementation of health promotion strategy in Integrated Service Post Park Program at The Public Healt Center Pesantren I Kediri City.Informants from this study consisted of 4 officers Integrated Service Post Park Facilitator.Data is collected by indepth interviews. Data is analyzed according to Colaizzi's stage data analysis. The findings of this study include : Empowerment activities, Social Support activities, Advocacy activities and Partnerships activities. In the implementation of empowerment activities found the training of facilitation officer and cadres are uneven and absence of special means for promotional activities of the Integrated Service Post Park Program. In the implementation of the activity of developing the social support found the existence of problem because of the absence of Early Childhood Education Programs cadres and insufficient means of Educational Game Tools. In the implementation of advocacy activities conducted policy proposals on the establisment of services of early child development cadres and addition of cadres and the addition means of educational game tools. In the implementation of partnership activities have been created a good coordination between the facilitation officers with the stakeholders but there are problems in the mechanism of distributing incentives for facilitation officers and cadres. Recommendations of this study is aimed to facilitation officer of Integrated Service Post Park in helping them to use appropriate health promotion strategies in implementing the Integrated Service Post Park Program activities.
\end{abstract}

Keywords : Facilitation Officer of Integrated Service Post Park, Integrated Service Post Park Program and Health Promotion Strategies.

\section{INTRODUCTION Background \\ Health is a human right as well as an investment, so it needs to be strived, strived and enhanced by every individual and by all components of the nation, so that people can enjoy healthy life, and ultimately can realize the optimal health status of society. Integrated Service Post is a strategic step in the development of human resources quality of the nation of Indonesia in order to build and help itself, so it needs to be enhanced \\ Health Department of Kediri City in 2016 stated that the achievement of officers Integrated Service Post Park faciliatation at Puskesmas Pesantren I Kota Kediri only $10 \%$ which entered the optimal category. To optimize the function of Integrated Service Post park, it is necessary to assist the cadres to evaluate and develop the Integrated Service Post Park. With this facilitation officer, it is expected that Integrated Service Post Park will provide better integrated services.} choacing (Ismawati, 2010). Since March 2012, East Java Provincial Government has launched 10,000 Integrated Service Post Parks in each village. Posyandu park program in East Java quantitatively until the year 2014 has been exceeded as many as 12,227 or an increase of $22.27 \%$ from the declaration of movement activities 10,000 Integrated Service Post parks starting from 2012. However, qualitatively in that year only $23 \%$ in the optimal category. While in 2015 reached $40 \%$ where the programs and policies that have been implemented more focused on improving the quality of services Integrated Service Post Park (Faiq N., 2017, surabaya.tribunnews.com). Data from

\section{Research purposes}

The purpose of this research is to know Implementation of Health Promotion Strategy in Integrated Service Post Park Program at Public Health Center Pesantren I Kediri City.

\section{Research focus}

The focus of this research is to know the implementation of empowerment activities, the activity of developing the atmosphere, the advocacy activities and the partnership activities in Integrated Service Post Park Program at Public Health Center Pesantren I Kediri City. 


\section{Benefits of research}

Benefit is the expected utility or research result that is can give input to officer of Posyandu park about the implementation of appropriate health promotion strategy to support progress in Integrated Service Post Park activity at Public Health Center Pesantren I Kediri city. This research is also expected to provide inputs to educational institutions as useful information and can be used as a reference from further research and also develop health promotion strategies that can support the Integrated Service Post Park Program.

\section{LITERATURE REVIEW}

\section{The Concept of Health Promotion Strategy}

The main basic strategies of Health Promotion are (1) Empowerment (2) Social Support (3) Advocacy, and imbued spirit (4) Partnership (Depkes RI, 2008). Health empowerment, health literacy and health promotion are placed within a comprehensive framework of approach. Movement of the community at the family or household level, this strategy is addressed to family members such as fathers, mothers who have social responsibility for their environment by becoming posyandu cadres. This strategy officer is aimed at primary target, covering the leaders of puskesmas, head of health office and community leaders. The objective is to increase staff motivation to help the community to help themselves in the health sector such as through group counseling, workshops, seminars, comparative studies and training (Notoatmodjo, 2007). Establishment of the atmosphere is an effort to create an atmosphere or social environment that encourages individuals, families and communities to prevent disease and improve their health and create a healthy environment and play an active role in every effort to implement health. Advocacy is the activity of providing assistance to the community by making decisions makers and policy makers in the health sector as well as other sectors outside the health that have influence on society. on health and regulation can create an environment that can affect healthy behavior can be realized in society (Kapalawi, 2007). In empowerment, cultivation of atmosphere and advocacy, the principles of partnership must be enforced. Partnerships are developed between Public Health Center health officers and their target (patients or other parties) in empowerment, cultivation and advocacy. In addition, partnerships have also been developed due to the awareness that to improve the effectiveness of health promotion, Public Health Center health workers must cooperate with various stakeholders, such as professional groups, religious leaders, NGOs, mass media, and others..

\section{Integrated Service Post Concept}

Integrated Service Post is a basic health activity organized from, by and for the community assisted by health petuigas in a working area of the Public Health Center, where the program can be implemented in hamlet, village hall or other places that are easily accessible by the community (Sulistyorini, et al , 2010). According to the concept of "Arrif", Integrated Service Post can be grouped according to the level of four (Sembiring, 2004), namely: Integrated Service Post Pratama, Posyandu Madya, Integrated Service Post Purnama and Integrated Service Post Mandiri. Lowering infant mortality rate, Maternal Mortality Rate (pregnant, childbirth and childbirth) . The goal of Integrated Service Post implementation is to cultivate Small Family Norms Happy Prosperous, Increase the participation and ability of the community to develop Health and Family Planning activities and other activities that support for the achievement of healthy and prosperous community, functioning as Mode Reproductive Family Movement, Family Resilience Movement and Family Economic Movement and Prosperous Family Economic Movement and collect the community's potential to actively participate in improving the health and wellbeing of mothers, infants, toddlers and families as well as reducing maternal, infant and underfive mortality rates.

\section{Integrated Service Post Park Concept}

Integrated Service Post Park is a fullservice or full-service posyandu provided with additional Early Childhood Education Programs and Family Toddler Choacing (Dinkes Provinsi Jatim, 2013). The activities of Integrated Service Post Park have a purpose, among others, Integrated Service Post which is aimed at early detection of infant growth, early childhood education, which aims for guidance aimed at children from birth to 6 years old through education stimulation to help growth and physical and spiritual development so that children have readiness in entering further education and Family Toddler Coaching aims to improve knowledge and skills of parents in the development of development of children 
aged 0-5 years. The assessment of Integrated Service Post Park is categorized into 2 (two) sections, namely: (1) Optimal Integrated Service Post Park and (2) Integrated Service Post Park Not Optimal yet. To determine the category of Integrated Service Post Park, several indicators were used such as facilities, cadres, services and guidance from each 3 (three) components, namely (1) Integrated Service Post, (2) Early Childhood Development Services and (3) Family Toddler Coaching (Dewi, et al., 2014).

\section{RESEARCH METHOD}

The type of this research is phenomenological study with qualitative approach with the focus of research directed to know the implementation or implementation of health promotion strategy in Integrated Service Post Park Program at Public Health Center Pesantren I Kediri City. The research location is in the working area of Public Health Center Pesantren I Kediri City and conducted research on September 2017. Sampling technique in this study using purposive sampling. The inclusion criteria of this research were Facilitation Officers of Integrated Service Post Park at Public Health Center Pesantren I of Kediri City who was willing to be an informant. The informant in this research is Integrated Service Post Park Facilitation Officer at Public Health Center Pesantren I Kediri City who have been willing to be informant for in-depth interview of structured that is amounted to 4 people

\section{EXPOSURE OF DATA AND RESEARCH FINDINGS}

Public Health Center Pesantren I is one of the government institutions of Kediri City Health Office located in the sub district of Pesantren Kediri, who rescued on Jl. Brig. Gen. Imam Bakri HP No.94 Pesantren Districts Kota Kediri by Phone Number (0354) 690355. Public Health Center Pesantren I Kediri City as main health center with working area covering 5 village namely Pesantren, Bangsal, Banaran, Blabak and Betet villages. Public Health Center Pesantren I Kediri City has 32 Integrated Service Post and all tiered Integrated Service Post Mandiri. The number of Posyandu Park as many as 32 Tapos but the amount of assistance is 18 Taman Posyandu. Integrated Service Post Park Facilitation Officers at Public Health Center Pesantren I Kediri City amounted to 6 people. The informants in this research are Integrated Service Post Park Facilitation Officer at Puskesmas Pesantren I Kediri City. From the results of research conducted with purposive sampling techniques obtained 4 informants. Informants aged 21-40 years as many as 2 informants and aged 41-60 years as many as 2 informants. All informants are female. Most informants have a high school education that is as much as 3 informants and educated junior high school is 1 informant. All informant job status is non goverment employees. Based on the results of the research, it is known that the implementation of health promotion strategy in Integrated Service Post Park Program at Public Health Center Pesantren I Kediri City which is related to the empowerment activity still running is not maximal because the giving of education or training to the Integrated Service Post Park Facilitation Officer and uneven cadre and the absence of special means for promotion or socialization of Integrated Service Post Park Program to the community. Based on the result of the research, it is known that the implementation of health promotion strategy in Integrated Service Post Park Program at Public Health Center Pesantren I Kediri which is related to the activity of developing the atmosphere there are obstacles in the process of Integrated Service Post Park activity due to the absence of Early Childhood Education Programs cadres in every Integrated Service Post Park so that the role is replaced by Early Childhood Education Programs teacher or escort officer Integrated Service Post Park, and inadequate means of Educational Game Tools used in the activities of Integrated Service Post Park. There were some minor conflicts between the officers of Integrated Service Post Park and the cadres, namely the problem of delay in the presence of cadres or Early Childhood Education Programs tutors and the problems of usage or monitoring of Educational Game Tools among the cadres. Based on the result of the research, it is known that in the implementation of health promotion strategy in Posyandu Park Program at Public Health Center Pesantren I Kediri related to advocacy activities, there is potential support and direction toward ideas or suggestions from Facilitation Officer of Integrated Service Post to the program holder Integrated Service Post Park in Public Health Center and local government. There is a need for policies to add infrastructure facilities for Integrated Service Post Park activities such as Educational Game Tools and Integrated Service Post equipment, the establishment of Early Childhood Education Programs cadres and the need for policies for the addition of cadres so that no double 
job or duplicate tasks are carried out by Facilitation Officers of Integrated Service Post Park. Based on the result of the research, it is known that in the implementation of health promotion strategy in Integrated Service Post Park Program at Public Health Center Pesantren I Kediri City related to the partnership activity that the implementation of coordination goes well between Facilitation Officer of Integrated Service Post Park with Integrated Service Post Park program holder at Public Health Center, City Health Office, Local Technical Implementation Unit of National Education and Family Planning Counseling. Conducting direct communication methods with community leaders and involving important figures in the community to establish good cooperation but never communicating or involving NGOs or mass media in activities of Integrated Service Post Park. There are problems related to the distribution mechanism of incentives for the Facilitation Officers of Integrated Service Post Park and cadres

\section{DISCUSSION}

In this research, the researcher get the description related to the implementation of health promotion strategy in Integrated Service Post Park Program by the Facilitation Officers of Integrated Service Post Park at the Public Health Center Pesantren I Kediri City. From this research, there are 4 themes: 1) implementation of empowerment activities, 2) implementation of social support activities, 3) implementation of advocacy activities, and 4) implementation of partnership activities.

\section{Implementation of Empowerment Activities in Integrated Service Post Park Program at Public Health Center Pesantren I Kediri City. \\ The concept of empowerment} emphasizes that people acquire the skills, knowledge and sufficient power to influence their lives and the lives of others concerned (Pearson et al, 1994 in Sukmaniar, 2007). The results of research on empowerment activities found that already implemented education or training to the Facilitation officers of Integrated Service Post, Integrated Service Post cadres, Early Childhood Education Programs cadres and Family Toodler Coaching cadres but not evenly given all the opportunities. Education or training is very important for Facilitation Officers of Integrated Service Post Park and Integrated Service Post cadres, Early Childhood Education Programs cadres and
Family Toodler Choacing cadres to improve their knowledge and skills in providing services in accordance with their duties and to increase the knowledge and ability to mobilize and empower the community. The results of research on empowerment activities on the implementation of monitoring of Facilitation Officers of Integrated Service Post Park on the performance of Integrated Service Post, Early Childhood Education Programs and Family Toodler Choacing cadres found that the implementation of the monitoring went well, including attendance observation, recording and documentation and evaluation discussion. Monitoring the performance of cadres is part of the evaluation process to monitor the shortcomings or the inability of the cadres in the implementation of their duties so that as soon as possible to be followed up with efforts to provide knowledge and increased empowerment to the cadres. According to Adedokun, et al., (2010) suggests that effective communication will lead to the active participation of community members in community development. The results of research on the implementation of activities to mobilize the community to increase the motivation and the active role of the community in following the activities of Integrated Service Post Park shows that the community mobilization activities conducted by Facilitation Officers of Integrated Service Post include the delivery of Integrated Service Post activities schedule, socializing in community activities and communicating directly at the activities of Integrated Service Post Park. Effective communication with delivery methods that are easily accepted and understood by the community will help increase the motivation of the community to take an active role in supporting the activities of Integrated Service Post Park. The findings of research in the implementation of empowerment activities indicate that in promotion activities or socialization Integrated Service Post Park Program to the community do not use media or facilities. Means or media needs to be used in promoting activities and socialization of Integrated Service Post Program to facilitate the delivery of the purpose and objectives of Integrated Service Post Park Program to the community.

\section{Implementation of Social Support Activities in Integrated Service Post Park Program at Public Health Center Pesantren I Kota Kediri.}


According to Stanley (2007), factors that influence social support should meet physical, social and psychological needs. Establish an atmosphere in service activities is an effort to create good coordination and effective communication in order to achieve success according to desired goals together. The findings of the research in the implementation of the activity of developing the atmosphere shows that in the coordination includes making the schedule of activities, the division of tasks among cadres, recording activities, and there are constraints in the Early Childhood Education Programs because of the lack of Early Childhood Education Programs cadres. In addition to performing the task of being a Facilitation Officers Integrated Service Post also doubles as a cadre Integrated Service Post and Family Toodler Coaching cadres. The availability of sufficient cadre personnel in accordance with the duties and roles of each cadre will greatly support the smoothness in coordination and service delivery in Integrated Service Post Park activities. Diamteo (1991) defines social support as support or assistance that comes from others such as neighbors, co-workers and others. The findings of research in the implementation of community development activities indicate that the communication approach to the community is done directly when there is activity of Integrated Service Post Park and also there is done during the meeting activity in the community that is Regular Social Gathering and Neighborhood Association or Citizens Association meeting. Support and active role of the community is an important part that can determine the success rate of the objectives of a sustainable Integrated Service Post Park activity to provide services to the community. According Effendi and Makhfudli (2009), cultivating atmosphere is creating a conducive situation to deceive the behavior of clean and healthy life. Clean and healthy life behavior can be created and developed if the environment supports. The findings of the research in the implementation of the activity of building the atmosphere found that the facilities or methods used in the activities of Integrated Service Post Park to create a comfortable and conducive environment for the cadres and the community that is used are Educational Game Tool, posters, flipcharts, stage puppets, comfortable with good sanitation. Educational Game Tool facilities are insufficient or insufficient in Integrated Service Post Park activities. While the method used is to communicate directly with the community at the time of activities Integrated Service Post Park. The activities of Integrated Service Post will run smoothly and create a comfortable and conducive environment if supported by adequate infrastructure facilities. Pierce (in Kail and Cavanaug, 2000: 30) defines social support as an emotional, informational or advisory source provided by people around the individual to deal with everyday problems and crises in life. The findings of the research in the implementation of the activity of building the atmosphere found that there is no conflict or big problem either between cadres and with society. Small problems arise when there are cadres who are late in the meeting and the problem of returning Educational game Tool loans between cadres in the service activities of Integrated Service Post. Alternative problem solving is done by communication between cadres and remind each other. Conflict or problem is potentially happening in every relationship or interaction between individual and group. Resolving conflicts early and in the right way will be able to minimize conflict that was previously small or light does not become a major conflict. Self-awareness and discipline needs to be applied to individual escort personnel and cadres so as not to disrupt the process of task and performance in service activities so as not to trigger conflict.

\section{Implementation of Advocacy (Advocacy) activities in Integrated Service Post Park Program at Public Health Pesantren I Kediri City.}

According to Hopkins (1990) advocacy is an attempt to influence public policy, through various forms of persuasive communication. In other words, advocacy is an effort or process to gain commitment, conducted persuasively by using accurate and precise information (Notoatmodjo, 2010). The findings of the research indicated that in the advocacy work it was found that the policies of both the Integrated Service Post Park program holders in the Puskesmas and the local government supported the performance of the Facilitattion Officers of Integrated Service Post and cadres, but needed to be re-examined about the policy for the addition of infrastructure for the activities of Integrated Service Post and the establishment of Early Childhood Educational Programs cadres. Strategic policies of stakeholders are needed to improve the shortcomings or constraints in operational activities of Integrated Service Post Park in order to improve the quality of 
service of Integrated Service Post park to the community. The findings of research in advocacy activities obtained information that there are no policies that hamper or reduce the performance of Facilitation Officers of Integrated Service Post Park and cadres either from the Posyandu Park program holders in Public Health Center and local government. According to Efendi and makhfudli (2009), advocacy is a leadership approach with the aim to develop sound public policy. The findings of the research in the advocacy activities of the feedback from the Integrated Service Post Park program holders in the Public Health Center and local government, on opinions in the form of criticism or suggestions from the Facilitation Officers of Integrated Service Post Park and the cadres as well as from the community regarding the established policies were obtained information that there is good response from the Integrated Service Post Park program holders in Public Health Center and local government, to suggestions or suggestions from Facilitation Officers of Integrated Service Post Park and cadres. Advocacy according to Depkes RI (2008) is a strategic or planned effort or process to get commitment and support from stakeholders. Advocacy is directed toward generating support that is a policy (eg in the form of legislation), funds, means and others like. Stakeholders in question can be formal community leaders who generally play a role as government policy makers and government funders. It can also be informal community leaders such as religious leaders, traditional leaders and others who can generally act as policy makers (not written) in their field. The findings of the research in advocacy activities showed that there was potential support and direction when there were ideas or suggestions from Facilitation Officer of Integrated Service Post Park to the Integrated Service Post Park Program holders in the Public Health Center and local government. The policies of the program makers are the key to the implementation of an activity. The need for reviews by organizers and implementers in the field to conduct monitoring and evaluation to find the inequality that occurs in an activity that raises the potential to provide a proposed policy revision or create a new policy better to improve the positive outcomes that the main objective of the activity.

\section{Implementation of Partnership Activities in Integrated Service Post Park Program at Public Health Center Pesantren I Kediri City.}

According to Ambar Teguh Sulistiyani (2004: 129) a partnership viewed from an etymological perspective adapted from the word partnership and rooted from the word partner. Partners can be translated as spouse, soul mate, ally, companyon, while partnership is translated as fellowship or partnership. Partnership in essence is known as cooperation from various parties, either individually or in groups. Partnership is really a necessity for parties with a common orientation that wants to save energy and generate multiple benefits. The result of the research shows that the partnership activity in coordinating coordination with Integrated Service Post cadres, early Childhood Educational Programs cadres and family Toodler Coaching cadres in terms of activities and follow up activities of Integrated Service Post Park is found that coordination is done during Integrated Service Post Park activities, by conducting a meeting or discussion to evaluate the activities of Integrated Service Post and make planning for the next activity. Beyond the activities of Integrated Service Post Park coordination is done by using the communication to create a group on WhatsApp social media among the cadres. Coordination is one of the vital parts in an effort to create a solid partnership relationship. Coordination is important to know the achievements and evaluate the constraints to each other so that it can make improvements to realize success in the direction and common goals. The results showed that the partnership activities in coordination with the program holders of Integrated Service Post Park in Public Health Center, City Health Office, Local Technical Implementation Unit of National Education and Family Planning Counseling in terms of activities and follow up activities of Integrated Service Post Park went well. Coordination is done at the time of reporting activity of Integrated Service Post Park which is reporting to City Health Office once in three month and for reporting to Public Health Center done once a year and reporting to Family Planning Counseling once a month while in scheduling paud cadre in activity of Integrated Service Post Park coordinate with Local Technical Implementation Unit of National Education. According to Ansarul Fahruda, et al (2005), to build a partnership, it must be based on the following things: common interest or interests, mutual trust and mutual respect, clear and measurable goals and willingness to sacrifice both time, energy and other resources. Partnership is a process of 
interaction of two or more parties that is realized in the form of cooperation. Participating parties include various sectors such as community groups, government agencies and non-governmental organizations. Some of these parties work together to achieve common goals based on their agreement, principles, and roles. The findings of research on the partnership activities related to the means or methods used by the Facilitation Officers of Integrated Service Post Park to maintain good cooperation with the community, community leaders, religious leaders, NGOs, mass media and others obtained information that to establish cooperation well done direct communication method with community leaders and involved involving important figures in the community in the activities of Integrated Service Post Park. During this time never communicate or involve NGOs or mass media in the activities of Integrated Service Post. According to Notoatmodjo (2003), partnership is a formal cooperation between individuals, groups or organizations to achieve a certain task or goal. Meanwhile, according to Depkes (2006) in the promotion of online health suggests that partnership is a relationship (cooperation) between two or more parties, based on equality, openness and mutual benefit (benefit). The findings of research on partnership activities related to facilities, facilities or awards given to the Facilitation Officers of Integrated Service Post Park and cadres by the Integrated Service Post Park Program Holders in Public Health Center and local government in order to develop and improve the Integrated Service Post Park services are informed that the facilities obtained are monthly incentives as escort officers and cadres, uniform facilities special activities, and incidental transport money when there is an invitation meeting. The obstacles are incentives that are not routinely received every once a month but given every six months. Partnership principles that refer to partnerships based on equality, openness and mutual benefit should be applied in a goal-oriented relationship. The awarding or reward that is in accordance with the achievement of the duty and the mechanism of granting the rights that must be obtained according to the rules and mutual agreement will support the smoothness in the process of activities carried out by each other.

\section{CONCLUSIONS AND SUGGESTIONS} Conclusion

Based on the results of the research, it is known that the implementation of health promotion strategy in Integrated Service Post Program at Public Health Center Pesantren I Kediri which is related to the empowerment activity still running is not maximal because the giving of education or training to the Facilitation Officers of Integrated Service Post and cadres are uneven and the absence of special means for promotion or socialization of Integrated Service Post Park program to the community. In the activity of developing the atmosphere there are constraint is becaused no Early Child Development Services cadres in every Integrated Service Post Park so that its role is replaced by Early Childhood Educational Programs teachers or facilitation officers of Integrated Service Post, and inadequate Educational game Tool facilities used in the activities of Integrated Service Post Park. There were some minor conflicts between the Facilitation officers of Integrated Service Post park and the cadres, namely the problem of delay in the presence of cadres or Early Childhood Educational Programs tutors and the problems of usage or monitoring of Educational Game Tool among the cadres. In the implementation of advocacy activities, there is potential for support and direction to the ideas or suggestions from the officers of Integrated Service Post Park Program holders in the Public Health Center and local government. There is a need for policies to add infrastructure facilities for Integrated Service Post Park activities such as Educational game Tool and Integrated Service Post equipment, the establishment of Early Childhood Educational Programs cadres and the need for policies for the addition of cadres so that no double job or duplicate tasks are carried out by facilitation officers of Integrated Service Post Park. Whereas in the partnership activity of coordination implementation went well between facilitation officers Integrated Service Post Park with Integrated Service Post Park Program holder in Public Health Center, City Health Office, Local Technical Implementation Unit of National Education and Family Planning Counseling. Conducting direct communication methods with community leaders and involving important figures in the community to establish good cooperation but never communicating or involving NGOs or mass media in activities of Integrated Service Post Park. There are problems related to the 
distribution mechanism of incentives for the falicitation officers of Integrated Service Post Park and cadres.

\section{Suggestion}

The results of this study is expected to be a form of description of the implementation of health promotion strategies in the implementation of Integrated Service Post Park Program in Public Health Center Pesantren I Kediri City so that it can be input for advocacy and negotiation with the relevant offices or stakeholders in making policies and overcome the problems arise in the implementation of Integrated Service Post Park activities. In addition, it can also be an input for the facilitation officers of Integrated Service Post Park to know and understand all the problems that arise in the activities of Integrated Service Post Park so that immediately make improvements by using the appropriate health promotion strategy and improve the quality of its performance to accelerate the achievement of Integrated Service Post Park target to be optimal.

\section{REFERENCE}

Alamsyah, E., dan Muliawati, R. 2013, Pilar dasar Ilmu Kesehatan Masyarakat, Penerbit Nuha Medika, Yogyakarta

Bungin, B. 2011, Metodologi Penelitian Kualitatif. Aktualisasi Metodologis ke Arah Ragam Varian Kontemporer, Penerbit PT. Raja Grafindo Persada, Jakarta

Bahar, B., Yusuf, Y., Syafar, M. 2010,Analisis Strategi Promosi Kesehatan di Puskesmas Bambalamotu dalam Pembinaan Masysrakat Suku Da'a di Desa Kasolong Kab. Mamuju Utara,Jurnal MKMI Vol.6 No.3, Juli 2010. Hal.141-145

Depkes RI. 2008, PedomanPelaksanaan Promosi Kesehatan di Puskesmas. Kepmenkes RI Nomor : 585/Menkes/SK/V/2007, Departemen Kesehatan RI Pusat Promosi Kesehatan, Jakarta

Dewi, P., Kiranasari, N.H., Werdiningtyas, D. 2014, Buku Saku Tugas Pendamping Di Taman Posyandu, Dinas Kesehatan Provinsi Jawa Timur

Faiq, N. 2017, Gerakan10.000 Taman Posyandu Melebihi Target, Surya.co.id. Diakses pada 5 Juli 2017 , http://surabaya.tribunnews.com
HSE.2011, The Health Promotion Strategic Frame Work, Published by HSE (Health Service Executive) National Health Promotion Office.

Julita, D. 2013, Taman Posyandu Jatim, Gerakan PAUD Berpihak Masyarakat Miskin, Kementrian Pendidikan dan Kebudayaan. Direktorat Jenderal Pendidikan Anak Usia Dini dan Pendidikan Masyarakat. Diakses pada 22 Juni 2017, http://pauddikmas.kemdikbud.go.id

Iskandar, M.N. 2016, Pelaksanaan Strategi Promosi Kesehatan dalam Program Perilaku Hidup Bersih dan Sehat (PHBS) Tatanan Rumah Tangga di Puskesmas Puuwatu Kota Kendari Tahun 2015, Skripsi, SKM, Jurusan Kesehatan, Fakultas Kesehatan Masyarakat, Universitas Halu Oleo, Kendari

Ismawati, C. 2008, Posyandu dan Desa Siaga. Panduan untuk Bidan dan Kader, Penerbit Nuha Medika, Yogyakarta

Kholid, A. 2015, Promosi Kesehatan. Dengan Pendekatan Teori Perilaku, Media, Dan Aplikasinya. Untuk Mahasiswa Dan Praktisi Kesehatan, Penerbit Divisi Buku Perguruan Tinggi PT. Rajagrafindo Persada, Jakarta

Machfoedz dan Suryani. 2009, Pendidikan Kesehatan Bagian dari Promosi Kesehatan, Penerbit Fitramaya, Yogyakarta

Notoatmodjo, S.2013, Promosi Kesehatan Global, Penerbit Rineksa Cipta, Jakarta

Notoatmodjo, S. 2010,Promosi Kesehatan. Teori dan Aplikasinya, Penerbit Rineka Cipta, Jakarta

Prasetyo. 2015, Konsep dan Teori Pemberdayaan Masyarakat. Diakses $\begin{array}{lll}\text { pada } & 7 & \text { Juli }\end{array}$ https://prasfapet.wordpress.com/2015/ 05/07/konsep-dan-teoripemberdayaan-masyarakat/

Putra, F.Y. 2016, Strategi Promosi Kesehatan Dinas Kesehatan Kabupaten Kutai Kartanegara Tentang Pemahaman Perilaku Hidup Bersih dan Sehat (PHBS) di Puskesmas Mangkurawang, eJurnal Ilmu Komunikasi. 4(1), 2016:74-87, ejournal.ilkom.fisip-unmul.org 
Rezeki, S., Mulyadi, A., Nopriadi, 2013,Strategi Promosi Kesehatan Terhadap Peningkatan Perilaku Hidup Bersih dan Sehat Individu Pada Masyarakat Perkebunan di Wilayah Puskesmas Seikijang Kab. Pelalawan, Jurnal Ilmu Lingkungan, ISSN 19785283, 2013:7 (1)

Saryono dan Anggraeni,M.D, 2013,Metodologi Penelitian Kualitatif dan Kuantitatif dalam Bidang Kesehatan,Penerbit Nuha Medika, Yogyakarta

Sugiyono, 2015, Metode PenelitianKuantitatif, Kualitatifdan $R \& D$, Penerbit CV. Alfabeta, Bandung

UNICEF, 2015, Unicef's Strategy for Health (2016-2030),Published by UNICEF Programme Division.

Utami, T. 2015, Pengelolaan Paud Terintegrasi Layanan Posyandu, Skripsi, S.Pd, Pendidikan Guru Pendidikan Anak Usia Dini, Fakultas Ilmu Pendidikan, Universitas Negeri Semarang 